\title{
Building competitive advantage through platform-based product family thinking: Case powerpacks
}

\author{
Jukka Ohvanainen, Esa Hietikko \\ Savonia University of Applied Sciences (FINLAND) \\ jukka.ohvanainen@,lut.fi; esa.bietikko@savonia.fi
}

Received November 2011

Accepted June 2012

\section{Abstract:}

Purpose: The purpose of this paper is to discuss through the main aspects and principles of successful platform-based product family development and management. For example car industry and car manufacturers take advantage of platform-based product families while solving the conflict of balancing between wide product variety and operational efficiency. This is a common dilemma also in some other manufacturing companies operating on versatile markets; how to serve individual customer needs with minimum development, manufacturing and service efforts? Product families are in this paper seen as an answer. Thus, the aim of this paper is to promote the adoption of often complex and risky product family development especially in technology and manufacturing focused companies. To be able to minimize risks and maximize the advantages companies need to understand the dynamics of the product family thinking presented in this paper.

Design/methodology/approach: After a literature survey the main aspects and principles of the product family thinking are illustrated through a case example from a company designing and manufacturing hydraulic piling equipment.

Findings: The case study shows that as universal practices are missing the "best practice" in product family development is always dependent on the nature of the company and its products. It is also evident that gaining long-term competitive 
advantage through product family thinking will not happen without continuous learning and investments in both time and resources.

Originality/value: This paper presents the main aspects and principles of the platform-based product family thinking in a systematic and hierarchical manner by connecting together platforming, architecture design, strategic aspects and management perspectives.

Keywords: product family, product platform

\section{Introduction}

Across many industries, increased competition, globalization and demand for value rich and customized products have enforced companies to begin thinking in more customer-oriented way while trying to maintain efficient production. One single product rarely contributes to long term success and competitiveness of a company. Instead of creating one product at a time it is often more profitable to design product families that satisfy a broader set of market-niches. However, due to it complex and often risky nature the product family development process is less adopted approach in comparison to single product development processes. Also the management of the product families requires new kind of practices. This paper will provide a brief overview of the product family thinking by using a product family case as an illustrative example. The aim of this paper is to create better overall understanding of the product family thinking and helping to understand how to get competitive advantages through the product families.

The structure of this paper is as follows: The section 2 discusses the background of the product family thinking on the basis of literature survey. Then, section 3 presents a case study built in co-ordination with Junttan Ltd, the company specializing in high technology hydraulic piling equipment. Finally, section 4 states conclusions including some further development proposals for the research activities related to product families. 


\section{The background of the product family thinking}

\subsection{Definitions and the dynamics of the product family thinking}

Product families are means to improve the commercial variety of the company while limiting the development, manufacturing and service efforts by standardization and reuse (Erens \& Verhurst, 1998, p. 174). Product family consists of technically related, but differentiated products that share a common platform and are aimed to serve variety of market niches within a particular market. Each member of the product family, called a product variant, has unique architecture. However, the goal of product family thinking is to make that architecture as common as possible across the whole family without compromising those particular individual characteristic's of a single variant, valued by customers. Product family should be planned in a way that the stream of derivative products can be efficiently created, produced and launched from the base of common platform to meet the existing and emerging market opportunities. (Meyer \& Lehnerd, 1997, p. 1 - 2, p. 39; Krishnan, Singh \& Tirupati, 1998). Figure 1 illustrates the main aspects that should be noted in order to be able to understand the dynamics of the product family thinking.

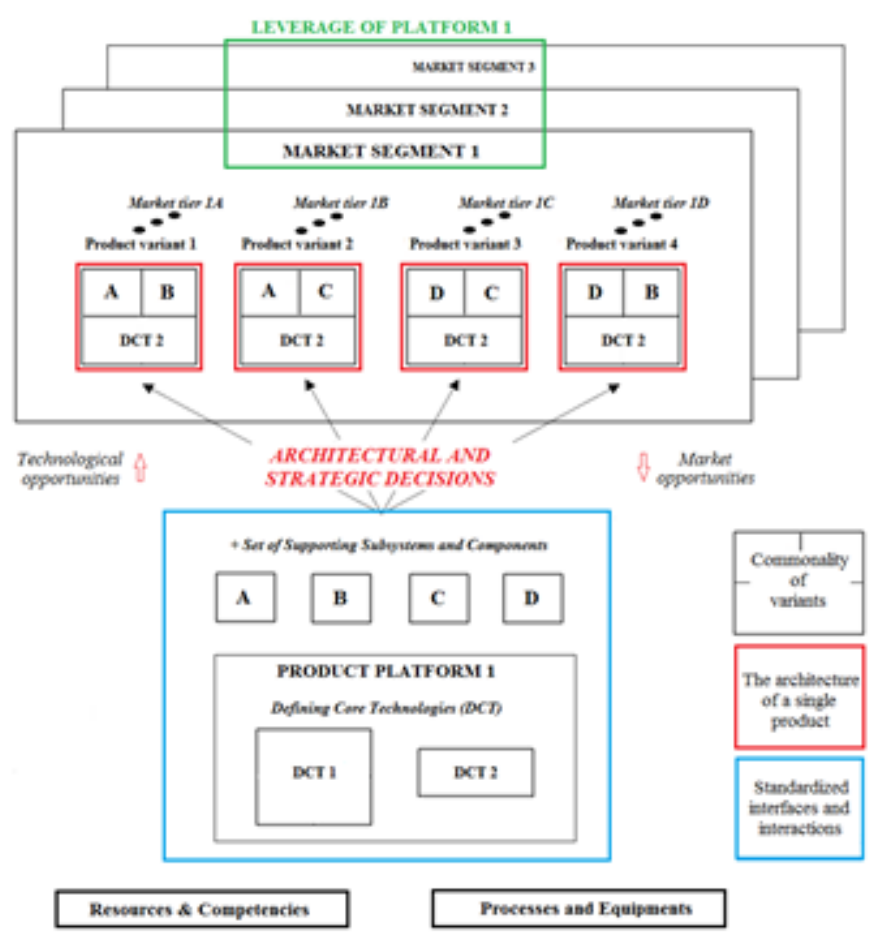

Figure 1 . The dynamics of the product family thinking

According to McGrath (2001, p. 53) "A product platform is a collection of common elements, particularly of the core technology elements, implemented across a 
range of products". Those core technology elements form the foundation of product family members, and remain constant from variant to variant, within a particular product family. Traditionally platform is seen as a set of parts, subsystems and interfaces, but it can also include non-physical aspects like people and knowledge. Core technologies can be stretched to individual variants with supporting elements, such as product or market specific components. The choice of the defining core technology is one of the most critical strategic decisions, because it will determine both capabilities and limits of the platform during its life cycle. Platform thinking provides market leverage and capability to stretch company's products to new market-niches due to evolving customer needs and new technological opportunities In other words platforms enable firms to offer global portfolios of products, while having response for regional differences in design, styling and regulations (Simpson et al., 2006, p. 3). (McGrath, 2001, p. 53-54; Meyer, 1997, p. 24-27; Gonzalez-Zugasti \& Otto, 2000, p. 1).

Decision to develop product families is often a strategic one because new resources and capabilities are normally needed in order to succeed. Therefore the commitment and desire to product family development must come from upper management. In many cases implementing product family strategy will not succeed without reorganizing organization structures. Restructuring the organization and getting both employees and network involved is essential and require strong commitment from the upper management. For example if a company consists of multiple separate business units, the key of successful platform development is to create structures with efficient ICT systems. (Simpson et al., 2006, s. 3-4) Platform strategy is the foundation of product strategy, because it defines the cost structure, capabilities and differentiation of the developed product variants (McGrath, 2001, s. 53). It should be noted that platform development requires investments in both time and resources. Profitability of these investments depends on the market size, number of products expected to be launched, and similarities among these products (Krishnan, 1998, s. 1$)$.

According to Soininen (1997, p. 23) product family thinking and mass customization are not synonyms: in mass customization the target of products is an individual customer when variants of product family are aimed to meet expectations of particular customer segments. Literature research reveals multiple ways to categorize product families. One common way is to divide them into scalable and modular product families. In modular product family features are transformed when adding, changing or removing modules. Modules shared across 
variants should include standardized interfaces and interactions to allow different compositions of products (Miller \& Elgaard, 1999). In scale-based family, features change through variants with different values of scalable variables, such as size, appearance or basic idea. Products share the same operational principle, but are planned to operate at different performance levels. (Messac, Martinez \& Simpson, 2002; Huhtala, 2009, p. 141; Hölttä-Otto, 2005, p. 33; Simpson, Maier \& Mistree, 2001, p. 3)

Creating the structure of a platform is an architectural decision, where designers must define which parts or functions are part of the platform and how do those interact (Whitney, 2004, p. 341). According to Ulrich and Eppinger (2008, p. 165) product architecture is the "scheme by which the functional elements of the product are arranged into physical chunks and the scheme by which the chunks interact". Physical chunks can be seen as a collection of physical elements like parts, components and subsystems. The architecture can be modular, integral or combination of these. Purely integral architecture is the one where single part performs all the functions whilst in modular architecture each function is assigned by its own individual element (Whitney, 2004, p. 345). Product family architecture (PFA) should be determined by taking manufacturability, functionality and technological feasibility into account (Jiao \& Tseng, 2000, p. 473). Thus PFA ought to be establish prior to the actual development process by teams consisting of professionals from different branches of expertise (Erens \& Verhulst, 1998, p. 170; Ulrich \& Eppinger, 2008, p. 171). Useful tools for determining architecture are for example modularity matrix, Erixon's MFD (Modular Function Deployment) and Steward`s DSM (Design Structure Matrix).

Successful product family development and management offers wide range of benefits for a manufacturing company, but also for customers. By reutilizing common components and platforms in product development designers can concentrate to the back end of a development process. Thus development costs of derivative variants are lower and those can be launched in faster pace to respond evolving market opportunities. Also the lead times are faster. Better gross margin and volume are results from reutilize, modularity and from ability to use economical production techniques. Modular product architecture is a good option for companies providing after sales services along with product, because modularity guarantees easier and faster service operations (Ericsson \& Erixon, 1999 , p. 20). The danger of product family development is that if the platform or some of its key systems are poorly designed, accumulating the flaws to every variant. For example too high degree of commonality can lead to loss in 
performance and competitiveness (de Weck \& Chang, 2003, s. 3). (Soininen, 1997, p. 43-46; Meyer, 1997 , p. 20)

\subsection{Product family development process}

Planning and developing the entire product family or more precisely product platform is more complex process than designing one single product at time. Hölttä-Otto (2005, p. 12) points out that the result of platform project should be a platform, not a single product. Platform creation is often time consuming and complex project, but once done properly, it economizes time, money and efforts in further development. Designers have to take multiple variables into account already during the "front end" of design process. Major challenge for the manufacturing company is to achieve both efficient production and large number of related product variants with minimal compromise in quality and performance. The development of product platforms should be done by cross-functional development teams, which share cross-functional information to ensure common architectures, component reduction, new ideas and even radical innovations. (McGill, 2004; Zha \& Sriram, 2006, p. 526; Simpson et al., 2006, s. 4; Soininen, 1997, p. 40)

Common ways to classify product family development approaches are top-down and bottom-up. In top-down approach a company creates product platform to derive variants, while managing product family based on that platform. In some cases creating totally new platform might be too rigorous and complex process. Bottom-up approach is used when the starting point of design process is a group of separate products. By redesigning or consolidating those products to standardized and reusable components, a company can enhance economies of scale. (Simpson et al., 2001, p. 3)

There is no generic or universal product family design process to be found from the literature. Zha and Sriram (2006) illustrate module-based product family process with eleven-step model. This process is represented essentially as follows:

- Decompose products into their representative functions

- Develop modules with one-to-one or many-to-one correspondence with functions

- Group common functional modules into a common product platform

- Standardize interfaces to facilitate addition, removal and substitution of modules 
Simpson et al. present five-step PPCEM (Product Platform Concept Exploration Method) to develop scale based product families using compromise DSP (Decision Support Problem) mathematical programming to model constraints and goals of the platform. The aim of the DSP is to determine the values of the design variables that provide maximum commonality and minimal performance losses. Salhied's methodology (2006, p. 1066) can be used if the goal of product a family development is to redesign heterogeneous product portfolio into homogeneous product families using different kinds of matrices. (Zha \& Sriram, 2006, p. 531532; Simpson et al., 2001, p. 4-6)

Those methods, found in the literature research, show that a common starting point of a product family development process is customer requirements and market analysis. Yang (2008, p. 89) reminds that it is the customer who will determine the price level, size of the market and the future trends for a product family and its variants. Zha and Sriram (2006) proposed DFD (Design Function Deployment) method as a starting point of module-based product family design process. Another well-known and widely used method is QFD (Quality Function Deployment) and especially the house of quality matrix. Simpson et al. (2001, p. 4) used market segment grid in their PPCEM method. In Salhied's method (2006, p. 1066), customer needs are recognized and identified; needs are translated into functions, thus generating a list of customer required functions.

\subsection{Management of product families}

Management of product families and platforms are an essential part of the company's product and technology strategy. Simpson et al. (2006, p. 8) pointed out that the platform strategy should be also a part of the company's overall business strategy. The competitive advantage for the future is built by developing and renewing constantly company's product portfolio with taking customer requirements and changing eras of technology and competition into account. There are three essential elements in managing product families and their evolution:

- The market applications of technology, i.e. derivative products offered for various customer groups

- The company's product platforms

- The common technical and organizational building blocks are the fuel for product platforms 
Common building blocks consisting of customer insights, product technologies, manufacturing processes and organizational capabilities needs to be updated occasionally. (Meyer \& Lehnerd, 1997, s. ix, 37, 50; Sjöholm, 2006)

Product families can be seen as generations (figure 2). Flexible platform is the key for deriving multiple product generations (Simpson et al., 2001, s. 7). To achieve long-term competitive advantage in the market a company must continually update its platform architecture and manufacturing processes. It is mainly the platform lifecycle that needs to be managed, not the individual product life cycle (McGrath, 2001 , p. 66). When variants are losing their competitiveness or market needs are changing, a platform modernization needs to be done. On the other hand managers must also react when the whole platform is out of date and thus needs to be replaced. (Meyer \& Lehnerd, 1997, s. 36-37; Simpson et al., 2006, s. 7-8)

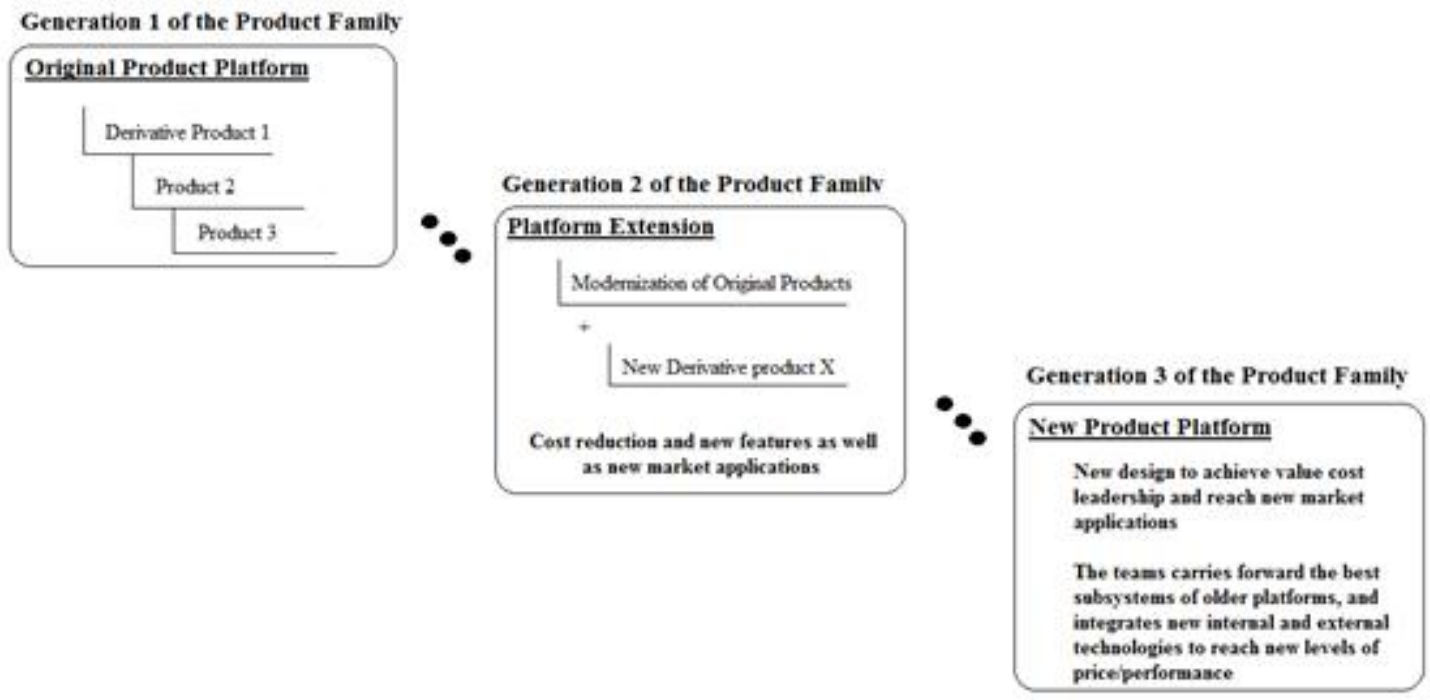

Figure 2. Product family evolution and platform renewal (Modified; Meyer \& Lehnerd, 1997,

$$
\text { p. 36) }
$$

Appropriate platform strategy can be chosen from three potential options: Horizontal, vertical and combination of both. Horizontal leverage is a strategy in which a platform is leveraged from one market niche to the next within a given tier of price/performance. In vertical scaling the company aspires to overtake a range of price/performance tiers within a market segment with common platform by scaling it down or up. Third potential option is the beachhead strategy. In this strategy horizontal leverage is combined with upward vertical scaling, so that lowcost but effective platform is developed initially and then scaled up to other levels. Scaling is made by adding features to products valued in other segments and tiers. (Meyer \& Lehnerd 1997, s. 54-63) 


\section{A case study: The X-series of powerpack product family}

\subsection{The background}

Powerpack is Junttan Ltd's brand name for its hydraulic power units. Junttan Powerpacks are designed and manufactured to be used alongside with company's own hammers, rotary heads and vibrators. Powerpacks are needed to produce hydraulic oil pressure for impact hammers. The 10XCU is the first launched member of the new X-series Powerpack product family. Junttan Ltd has made the strategic decision to launch at least 15XCU and 20XCU models while keeping the option of even more powerful model. Figure 3 below illustrates 10XCU Powerpack. (Junttan Ltd, 2011; Silvast, 2010)

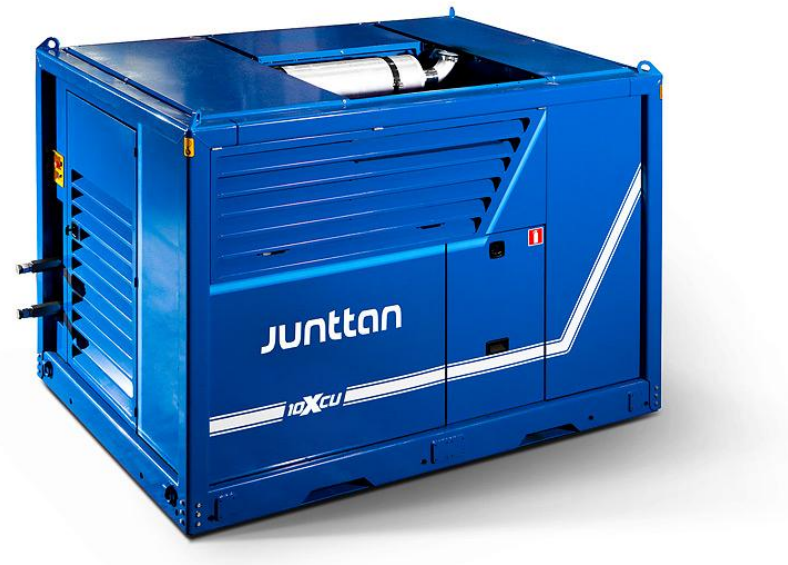

Figure 3. The 10XCU Powerpack (Junttan Ltd, 2011)

The main internal components of Powerpacks are engine, engine cooler, pumps, fuel and oil tank, oil coolers and electric cabin. The exterior components are frame, capping and hatches. (Silvast, 2010)

\subsection{The X-Series product family formation}

Product variants of the $\mathrm{X}$-series will share the same operational principle but are planned to operate at different performance levels. Therefore the $\mathrm{X}$-series can be seen as scale-based product family. The main variable between product family members is the hydraulic oil pressure generated by power unit. For example the 20XCU will offer more hydraulic oil pressure than the 10XCU. On the other hand, the X-series Powerpacks consist of both modular and scalable components which will be discussed later in this paper. 
The design process of the 10XCU was carried out by using product development method more suitable for single products. Even so, networks were involved in the design process and incoming variants were taken into account. The 10XCU was created by redesigning and consolidating existing products to standardized and reusable components. Therefore the approach of designing $\mathrm{X}$-series product family is the bottom-up. The 10XCU is the most standardized product in Junttan's product portfolio, offering faster time of delivery, a feature valued among Junttan's customers. Standardizing also eases the service operations, minimizes stocks, speeds up assembly, simplifies supply and most importantly allows leverage of platform.

\subsection{Strategic decisions}

The 10XCU forms the base of the X-series product platform, so in this case the low cost but effective platform was developed initially. Future variants 15XCU and 20XCU will be designed to meet the expectations of higher price/performance market tiers. Those incoming variants are derived from initial platform by scaling the platform up. Scaling is done by adding features to the platform that enables $15 \mathrm{XCU}$ and 20XCU to reach higher performance/price levels. In terms of Meyer and Lehnerd (1997) the platform strategy is the beachhead as illustrated in Figure 4 below.

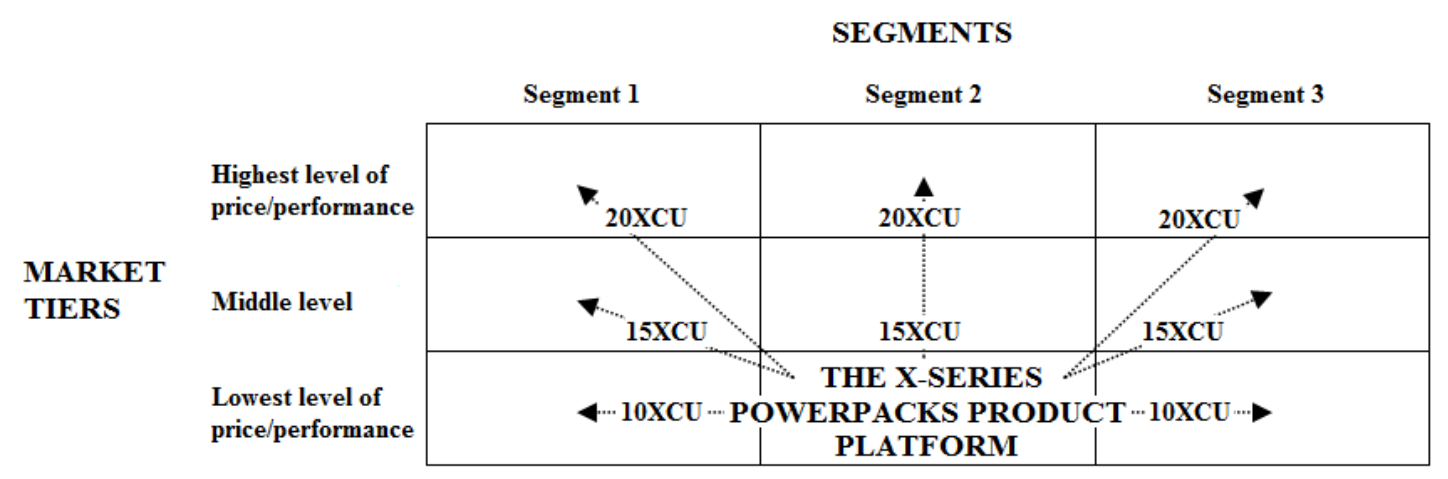

Figure 4. The beachhead platform strategy of the X-series Powerpack product family

Defining the actual market segments in the case of Powerpacks is a difficult task. In this case market segments are formed by the market areas of Powerpacks as illustrated in figure 5 . Segments differ from each other by engine specification requirements, but also because of climatic differences. The main segments AsiaPacific, Europe and USA are supplemented by others. Market tiers are defined on the basis of required power class. The 10XCU reaches the price/performance level 1 , whereas the performance requirements of levels 2 and 3 are attained by units $15 X C U$ and $20 X C U$. 


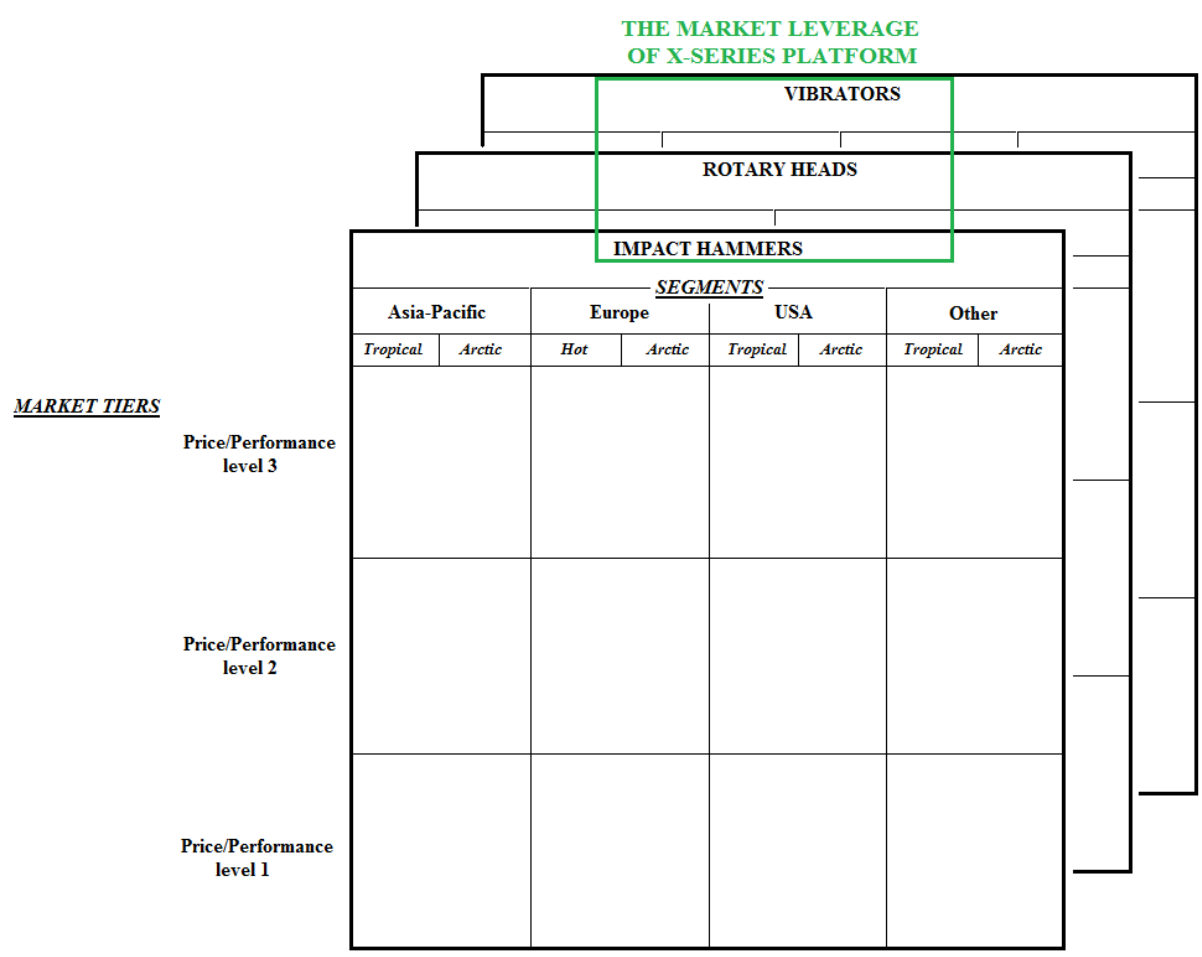

Figure 5. Segments and market tiers of the X-series Powerpacks

Changing engine emission standards have to be taken into account by the designers. The challenge is to design interfaces in a way that different engines and coolers fit the same base. For example in Europe the engine emission standard is called Stage and in the USA Tier classification is used. Currently in Europe the engine should fulfill Stage III B requirements but in 2014 the standard will be Stage 4. In USA the equivalent change is from Tier $4 \mathrm{i}$ to Tier 4 final. In principle Australia requires the newest emission standards. In other countries emission requirements vary. It is important to get relevant and updated information from engine supplier when future changes are prepared. Climatic conditions have an impact on the choice between tropical or arctic package. The standard is the tropical package. The arctic package includes different kinds of oils and a preheating system for the engine, batteries and hydraulic oils.

\subsection{Product platform and supporting elements}

The product platform and supporting elements of the X-series Powerpack product family were defined by mapping components and subsystems that are shared across all product variants. The target was to define both the platform and the supporting elements by marking every components and subsystems of the X-series product family with $\mathrm{S}$, I or $\mathrm{O}$. These elements and the resulting product platform as well as the supporting elements are mapped in figure 6 . In this case supporting 
elements were divided into two groups: Supporting elements 1 are the key for creating product variants for particular market niche by scaling up the initial platform. In other words both segment specific requirements and the price/performance level are adjusted with supporting elements 1. By adding supporting elements 2 the variants can be further configured inside that niche to meet the specific requirements of an individual customer or a project.

\begin{tabular}{|c|c|c|c|c|}
\hline $\begin{array}{l}\text { COMPONENTS \& } \\
\text { SUBSYSTEMS }\end{array}$ & $10 \times C U$ & $15 \mathrm{XCU}$ & $20 \mathrm{XCI}$ & \\
\hline Tubing and adapters, & IO & IO & IO & \multirow{5}{*}{$\begin{array}{l}\text { Supporting } \\
\text { elements } 2\end{array}$} \\
\hline iPiler, & $\mathrm{O}$ & 0 & 0 & \\
\hline Worksurfaces, & $\mathrm{O}$ & o & 0 & \\
\hline Colour and stickers, & 0 & 0 & $\mathrm{O}$ & \\
\hline Special oils & $\mathrm{O}$ & $\mathrm{O}$ & $\mathrm{O}$ & \\
\hline Side capping, & I & $\mathrm{S}$ & $\mathrm{S}$ & \multirow{7}{*}{$\begin{array}{l}\text { Supporting } \\
\text { elements } 1\end{array}$} \\
\hline Side frame & I & $\mathrm{s}$ & $\mathrm{s}$ & \\
\hline Engine, & I & I & I & \\
\hline Oil pump, & I & I & I & \\
\hline Oil cooler, & I & $\mathrm{s}$ & $\mathrm{s}$ & \\
\hline Tanks, & I & I & I & \\
\hline Arctic/Tropical package & so & so & so & \\
\hline Urea tank, & $\mathrm{S}$ & $\mathrm{S}$ & $\mathrm{s}$ & \multirow{17}{*}{\begin{tabular}{|}
$\mid$ \\
THE PRODUCT \\
PLATFORM
\end{tabular}} \\
\hline Exhauster, & $\mathrm{s}$ & $\mathrm{s}$ & $\mathrm{s}$ & \\
\hline Flow control block, & $\mathrm{s}$ & $\mathrm{s}$ & $\mathrm{s}$ & \\
\hline Mechanical control box of & $\mathrm{s}$ & $\mathrm{s}$ & $\mathrm{s}$ & \\
\hline engine and hammer, & $\mathrm{s}$ & $\mathrm{s}$ & $\mathrm{s}$ & \\
\hline Oil collection block, & $\mathrm{s}$ & $\mathrm{s}$ & $\mathrm{s}$ & \\
\hline Percolating filter, & $\mathrm{S}$ & $\mathrm{s}$ & $\mathrm{s}$ & \\
\hline Hydraulic accumulator, & $\mathrm{s}$ & $\mathrm{s}$ & $\mathrm{s}$ & \\
\hline Oil filling pump and & $\mathrm{s}$ & $\mathrm{s}$ & $\mathrm{s}$ & \\
\hline adjustable valves & $\mathrm{s}$ & S & $\mathrm{s}$ & \\
\hline Fuel filters/separator, & $\mathrm{s}$ & $\mathrm{s}$ & $\mathrm{s}$ & \\
\hline Expansion tank, & S & $\mathrm{s}$ & $\mathrm{s}$ & \\
\hline Fuel pump, & $\mathrm{s}$ & S & s & \\
\hline Batteries, & $\mathrm{s}$ & $\mathrm{S}$ & $\mathrm{s}$ & \\
\hline Oil drainage launder, & $\mathrm{s}$ & $\mathrm{s}$ & $\mathrm{s}$ & \\
\hline Hydraulic block, & $\mathrm{s}$ & $\mathrm{s}$ & $\mathrm{s}$ & \\
\hline Oil change pump & $\mathrm{s}$ & $\mathrm{S}$ & S & \\
\hline Face capping, & $\mathrm{s}$ & $\mathrm{s}$ & $\mathrm{s}$ & \\
\hline Face frame & $\mathrm{s}$ & $\mathrm{s}$ & $\mathrm{s}$ & \\
\hline $\mathrm{S}=$ SHARED & & & ION & \\
\hline
\end{tabular}

Figure 6 . The X-series product platform and the supporting elements

The 15XCU and the 20XCU must generate more oil pressure into hammers than the 10XCU. Therefore they need bigger oil pumps, more efficient engines, bigger tanks and bigger coolers. Increased need for oil cooling is arranged by adding one extra oil cooler module into the 15XCU and the 20XCU. Due to these changes side capping, side frame and tanks are scaled up while the length of the power units is increasing.

\subsection{Architectures}

The architecture of the power unit variants remains almost constant across the product family. The architecture of the X-series Powerpacks was determined by taking the aspects of manufacturability, functionality and technological feasibility into account. The Powerpacks are designed to reduce production costs and lead 
time, as well as to ease the usage and service operations. Therefore the architecture of the X-series product family is mainly modular.

The architecture of the 10XCU is duplicated into the 15XCU and the 20XCU with little differences. Face dimensions of Powerpacks are defined by taking into account the dimensions of the freight container. All product variants of the X-series family will fit into the container even though the length of the 15XCU and 20XCU is scaled up. Scaling the length up will not have an essential influence on the architecture, because the positions of the main functional elements will not chance. All members of the product family include both technical and hydraulic sections which are clearly separated from each other. Clear functional zoning and roomy architecture are beneficial for manufacturability and functionality.

The frame of the Powerpacks is the outermost component in order to protect inner components from impacts. The roomy architecture and capping are appropriate considering air flows and cooling. Frame is deliberately roomy for components to allow easier maintenance and platform leverage. The roomy architecture is also optimal in order to prevent tube breaks when unit vibrates. All members of the $X$ series Powerpack product family will be easily movable in construction site due to lifting points are located both on top and bottom. Bended frame profile is cheap to manufacture and it also enables appropriate joints.

\subsection{Process and the supply chain}

All the individual components used in the Powerpacks are purchased directly from subcontractors or manufacturers. Those components and parts are then assembled trough manual labor into larger subsystems in Junttan's manufacturing department. After the modular steel structure is assembled, subsystems are then added in with cranes. Painting of the steel structure and manufacturing of capping are done by subcontractors. The modular steel structure allows efficient transportation of parts within the supply chain because parts can be packed tightly. Modularity also enables the scaling of the 15XCU and 20XCU side structures with the help of intermediate modules. The aim in the future is that the steel structure of the Powerpacks is purchased and transported in series of five in order to reduce costs. Most of the components used in the Powerpacks can be delivered rapidly from the suppliers' stocks. 


\subsection{Management and evolution}

The X-series Powerpack product platform will undergo substantial update at the latest in 2014 when new engine regulations are expected to come in force. Before that it is highly important that possible faults of the 10XCU are taken into account and repaired immediately. Otherwise those faults will duplicate into other family members through the common product platform. Junttan Ltd must also continuously monitor the market, competitors and technological opportunities in order to be ready to react if the platform needs updates or modernization.

The lifecycle of the X-series product family is assumed to be about 10-15 years. However the modular architecture and high degree of standardization enables even longer lifecycle for the individual Powerpacks. This is because the individual machines can be modernized with update modules while the platform and its parts evolve. A possibility to transfer the platform evolution for individual machines gives Junttan Ltd a better chance to achieve higher service revenues. The initial X-series product platform allows the product family extension with minimal front end design efforts. For example by combining two 20XCU into one, the result is the new and powerful X-series product family member. With this new member Junttan Ltd could reach higher levels of price/performance than shown in figure 5 . However the market will eventually decide whether it is reasonable or not to launch new product variants.

\subsection{The summary of the case}

The development process of the X-series Powerpack product family has been an important learning process for Junttan Ltd. Although development included some aspects from single product development process, it also challenged Junttan Ltd to think differently. Developing the entire family of products has brought multiple advantages for the company. The major advantage is that well designed product platform complemented by supporting elements and the appropriate modular product family architecture enables a wide variety of value-rich and differentiated products while limiting the costs through simplified procurement and assembly. Also, as a result of careful planning, the $\mathrm{X}$-series product platform will offer many further development possibilities through its evolution.

In the future Junttan Ltd should put more focus on the segmentation. Through its history the company has designed and manufactured highly customized products. The nature of Junttan's products will always require some customer- or projectspecific features but segmentation is crucial in order to gain maximum benefits 
from product families. By defining the product platform and supporting elements 1 on the basis of segments the company can maximize component sharing and reuse. The aim of the product family development should be that the final customerspecific customization is done with minimum number of supporting elements 2 . Whenever Junttan Ltd succeeds to replace customer-specific parts by segmentspecific ones, it is always a step toward cost savings, efficient supply chain and easier spare parts delivery.

\section{Conclusions}

Creating product families on the base of platforms is a slow, risky and complex process. However, the successful product family and platform development offers beneficial competitive advantages that cannot be ignored in modern technology company. The degree of complexity and risk can be reduced by starting the adoption of product family thinking from simplest and strategically secondary product groups. After, the learning process it is easier and less risky to proceed into more important product groups. The more a company's product portfolio comprises of component, recourses and effort sharing product families, the greater the benefits are.

As resource guards, managers have an essential role in bringing product family thinking into the company's activities. Employees and networks need both training and time to be able to learn and adopt all aspects of the product family thinking. When managers create product and competitive strategies on the base of product families, they have to ensure that employees have sufficient skills and tools to implement those. Continuous learning, innovativeness and strong commitment across the value network is the key for creating core competencies through product family thinking, and thus gain long-term competitive advantage in the market.

Successful product platform evolution enables continuous stream of incremental innovations. By using cross-functional teams and multidisciplinary information in design and development process also the possibility for radical innovations will increase. Technology companies should therefore put more focus on development of multi-technology product platforms. When combining different fields of expertise in product platform development process, the result might be variety of radically innovative product variants that chance the rules in the market. Radical multitechnology consisting platform is also more difficult to imitate by competitors. Thereby the competitive advantage is much deeper inside the platform due to 
accumulated silent knowledge. Also a chance that derived variants will attain the market domination position is higher.

More academic research is needed in the field of combining product family thinking, open innovation principles and value networks together. The innovativeness of every single employee, customer, subcontractor or network partner should be collected, transformed and used in order to create new generations of innovative product platforms and product families. While the product family thinking is becoming a part of the everyday business in many technology companies, more attention is needed for development of design software that is capable to assist in product family development. In the future also the demand for training services that concentrate on the product family and platform development will presumably increase. As a final conclusion it is evident that the science around the product families "is relatively" young. Even so it offers countless possibilities for companies that are willing to create their own "best practices" through learning and rethink.

\section{References}

de Weck, O.L., \& Chang, D. (2003). Product family and platform portfolio optimizing. Proceedings of ASME Design engineering Technical Conference. Chicago, Illinois, USA.

Erens, F., \& Verhulst, K. (1998). Architectures for Product Families. Computers in Industry, 33(2-3), 165-178. http://dx.doi.org/10.1016/S0166-3615(97)00022-5

Ericsson, A., \& Erixon, G. (1999). Controlling design variant: Modular product platforms. Michigan: Society of Manufacturing Engineers. ISBN: 978-0872635142.

Gonzalez-Zugasti, J. P., \& Otto, K. N. (2000). Modular platform-based product family design. Proceedings of DETC'OO ASME Design Engineering Technical Conferences and Computers and Information in Engineering Conference, September 10-13, Baltimore, Maryland.

Hölttä-Otto, K. (2005). Modular product platform design. Doctoral Thesis. Espoo: Helsinki University of technology. Department of Mechanical Engineering.

Huhtala, P., \& Pulkkinen, A. (2009). Tuotettavuuden kehittäminen -Parempi tuotteisto useasta näkökulmasta. Tampere: Teknologiateollisuus ry. $431 \mathrm{~s}$. 
Jiao, J., \& Tseng, M. M. (2000). Fundamentals of product family architecture. Integrated Manufacturing Systems, 11(7), 469-493. http://dx.doi.org/10.1108/09576060010349776

Junttan Ltd. (2011). Retrieved 2011, July 20, from http://www.junttan.fi/about us

Krishnan, V., Singh, R., \& Tirupati, D. (1998). A model-based approach for planning and developing a family of technology-based products. The University of Texas at Austin. Retrieved July 20, 2011 from http://citeseerx.ist.psu.edu/viewdoc/download?doi=10.1.1.17.8994\&rep=rep1\&type=pdf

McGill, M. (2004). Aligning a platform-based approach to product strategy a case study of new vaccine development to licensure. Platform Management for Continued Growth. Atlanta, GA, IIR/PDM.

McGrath, M. E. (2001). Product strategy for high-technology companies. Accelerating your business to web speed (2nd Ed.). McGraw-Hill companies. ISBN 0-07-136246-0

Messac, A., Martinez, M.P., \& Simpson, T.W. (2002). Effective product family design using physical programming. Engineering Optimization, 34(3), 245-261. http://dx.doi.org/10.1080/03052150211746

Meyer, M. H., \& Lehnerd, A. P. (1997). The power of product platforms: Building value and cost leadership. New York: The Free Press. ISBN-13: 9781451655308

Meyer, M.H. (1997). Revitalize your product lines through continuous platform renewal. Research Technology management, 40(2), 17-28.

Miller, T. D., \& Elgaard, P. (1999). Structuring principles for the designer. Proceedings of the 1999 CIRP International Design Seminar: Integration of Process Knowledge into Design Support System. ISBN 0-7923-5655-1.

Salhied, S. M. (2006). A methodology to redesign heterogeneous product portfolios as homogeneous product families. Computer-Aided Design, 39(12), 1065-1074. http://dx.doi.org/10.1016/j.cad.2007.07.005

Silvast, T. (2010). Hydraulisen Voimayksikkötuoteperheen teräsrakenteen kehittäminen. Final Project. Kuopio: Savonia University of Applied Sciences. Mechanical Engineering. 978-952-203-123-5. 
Simpson, T. W., Maier, J., \& Mistree, F. (2001). Product platform design: Method and application. Research in Engineering Design, 13(1), 2-22.

Simpson, T. W., Marion, T., de Weck, O., Hölttä-Otto, K., Kokkolaras, M., \& Shooter, S. B. (2006). Platform-based design and development: Current trends and needs in industry. Proceedings of the ASME International Design Engineering Technical Conferences \& Computers and Information in Engineering Conference September 10 - 13, Philadelphia, USA. http://dx.doi.org/10.1007/s001630100002

Sjöholm, H. (2006). Pk-yrityksen liiketoiminnan kehittäminen. Teknologia ja innovaatiot hyödyksi. (3rd Ed.). Helsinki: Tekes. Retrieved 2011, June 08, from: www.tekes.fi/fi/document/42918/teknologia ja kilpailukyky pdf

Soininen, J. P. (1997). Asiakastarvelähtöisyys elektronisen tuoteperheen suunnittelussa. [www-publication] VTT Julkaisu 822. Espoo: Valtion teknillinen tutkimuskeskus. Retrieved May 25, 2011， from http://www.vtt.fi/inf/pdf/julkaisut/1997/J822.pdf

Ulrich, K. T., \& Eppinger, S. D. (2008). Product design and development. (4th Ed.). New York: McGraw-Hill Companies. ISBN: 978-007-125947-7.

Whitney, D. E. (2004). Mechanical assemblies - their design, manufacture, and role in product development. New York: Oxford University Press. 978-1-60119-337-7.

Yang, K. (2008). Voice of customer: Capture and analysis. New York: The McGrawHill Companies. 978-1-61583-059-6.

Zha, X. F., \& Sriram, R. D. (2006). Platform-based product design and development: A knowledge-intensive support approach. Knowledge-Based Systems, 19(7), 524-543. http://dx.doi.org/10.1016/j.knosys.2006.04.004

Journal of Industrial Engineering and Management, 2012 (www.jiem.org)

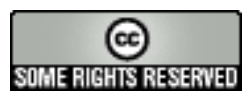

\footnotetext{
Article's contents are provided on a Attribution-Non Commercial 3.0 Creative commons license. Readers are allowed to copy, distribute and communicate article's contents, provided the author's and Journal of Industrial Engineering and Management's names are included. It must not be used for commercial purposes. To see the complete license contents, please visit http://creativecommons.org/licenses/by-nc/3.0/.
} 